\title{
Perancangan Sistem Kontrol Otomatis Berbasis Web Menggunakan Raspberry Pi 3 pada Smarthome
}

\author{
Wais Al-Qorni ${ }^{1}$, Anugrah Azhar ${ }^{1}$, Elvan Yuniarti ${ }^{1, \uparrow}$ \\ ${ }^{1}$ Program Studi Fisika, Fakultas Sains dan Teknologi, Universitas Islam Negeri Syarif Hidayatullah \\ Jakarta, Jalan. Ir. H. Djuanda No.95, Cempaka Putih, Ciputat, Kota Tangerang Selatan, Banten 15412, \\ Indonesia \\ †elvan.yuniarti@uinjkt.ac.id
}

\begin{abstract}
Abstrak. Biasanya manusia mengontrol perangkat elektronik rumah dengan cara manual tetapi dengan penerapan rumah cerdas maka perangkat elektronik dapat dikontrol dengan menggunakan satu pengontrol pusat saja. Berdasarkan hal tersebut maka diperlukan sebuah mini pc yaitu sebuah perangkat komputer kecil atau mini. Mini pc yang digunakan adalah Raspberry pi, dengan Raspberry Pi yang menerapkan teknologi jaringan wireless dan wire yang dihubungkan dengan teknologi smartphone yang saat ini menjadi reward dalam perkembangan dunia teknologi. Tujuan penelitian ini adalah mendapatkan kemudahan dalam mengontrol perangkat elektronik yang ada didalam rumah dengan cara pengontrolan terpusat pada sebuah smartphone android. Sistem yang dirancang untuk mengontrol aktif dan non-aktif. perangkat seperti lampu, kipas angin, dan televisi ini dirancang dengan menggunakan LXTerminal pada raspbian, bahasa Python dan Android Studio sebagai sarana untuk membuat perangkat lunaknya. Pengujian dilakukan dengan menampilkan beberapa menu pada display aplikasi disertai dengan meletakkan seluruh perangkat keras yang sudah disusun dengan baik. Hasil pengujian menunjukkan bahwa perangkat elektronik seperti lampu, kipas angin, dan televisi berhasil dilakukan pengontrolannya (aktif dan non-aktif).
\end{abstract}

Kata Kunci: Raspberry Pi, Android Studio, Smartphone, LXTerminal, Python, Perangkat Elektronik.

Abstract. Normally humans control the home electronic devices by hand but with the application of intelligent home electronic device can be controlled using just one central controller. Under these conditions, we need a mini PC is a small computer device or a mini. Mini PC is used Raspberry Pi, the Raspberry Pi that implement wireless networking technology and a wire connected with smartphone technology which is currently a reward in the development of the technology world. The purpose of this study is to get the ease of controlling an electronic device that is inside the house by way of centralized control on an Android smartphone. A system designed to control the active and non-active devices such as lights, fans, and television is designed using LXTerminal on raspbian, Python and Android Studio as a means to make its software. Testing is done by displaying some of the menus on the display application is accompanied by putting all the hardware that has been prepared well. The test results showed that electronic devices such as lights, fans, and television successfully performed the controlling (active and non-active).

Keywords: $\quad$ Raspberry Pi, Android Studio, Smartphone, LXTerminal, Python, Electronic Devices.

\section{PENDAHULUAN}

Seiring dengan berkembangnya Internet of Thinks (IoT), hal ini berdampak pada dimanfaatkannya internet untuk keperluan pendukung pembelajaran, salah satunya sebagai sistem kontrol otomatis jarak jauh menggunakan mikrokontroler. Penerapan dari IoT ini berupa pengendalian perangkat elektronik rumah menggunakan mikrokontroler Raspberry Pi 3 atau yang kita kenal sebagai Home Automation atau Smart Home. Smarthome merupakan teknologi kendali otomatis yang mengontrol benda-benda elektronik, pada rumah, kantor dan lainnya hanya lewat jaringan. Smarthome juga merupakan pemanfaatan teknologi komunikasi lainnya seperti smartphone dan jaringan internet yang terkoneksi dengan Wi-Fi dan dengan bantuan Raspberry $P i$ dengan mudah nya untuk mengontrol perangkat elektronik lainnya.

Untuk pengoptimalan mengontrol penggunaan perangkat listrik tentunya dapat dioptimalkan dengan memanfaatkan teknologi. Pengoptimalan dengan menggunakan smartphone berbasis internet dirasa cocok untuk menjadikan pekerjaan mengendalikan perangkat listrik 
dalam rumah menjadi efisien. Sering ditemukan permasalahan dimana remote kontrol penggunaan barang elektronik hanya dapat digunakan untuk satu jenis barang elektronik. Namun jika menggunakan smartphone berbasis jaringan internet diharapkan dapat menciptakan smarthome yang dapat mengatur segala penggunaan barang elektronik dalam rumah.

Berdasarkan solusi tersebut, maka dilakukan suatu penelitian yang dapat menjawab bagaimana cara merancang dan membangun prototype smarthome sederhana, namun difokuskan untuk kebutuhan pada saat melakukan banyak pekerjaan yang menghambat pergerakan untuk mematikan atau menghidupkan barang elektronik dalam rumah. Untuk membuat konsep ini maka dibutuhkan alat yang dapat mengontrol layak nya remote control tapi dalam jangkauan yang tidak terbatas dan mengontrol banyak hal. Di sini penulis memakai Raspberry Pi 3 sebagai pengatur utama agar konsep yang diinginkan berjalan dengan baik dan mengkoneksikannya dengan jaringan internet berbasis web agar pengendalian tidak terbatas oleh jarak dan tempat. Telah banyak dilakukan penelitian yang sama tentang smarthome selain menggunakan Raspberry Pi yaitu antara lain menggunakan Arduino dll sebagai mikrokontroler dan meneliti hanya bagian nya saja seperti menggunakan Bluetooth, Wi-Fi, Infra Red.

\section{METODE PENELITIAN}

Penelitian ini meliputi beberapa tahap. Secara garis besar tahapan tersebut terbagi atas perancangan alat, pembuatan program (koding) dan pengujian alat.

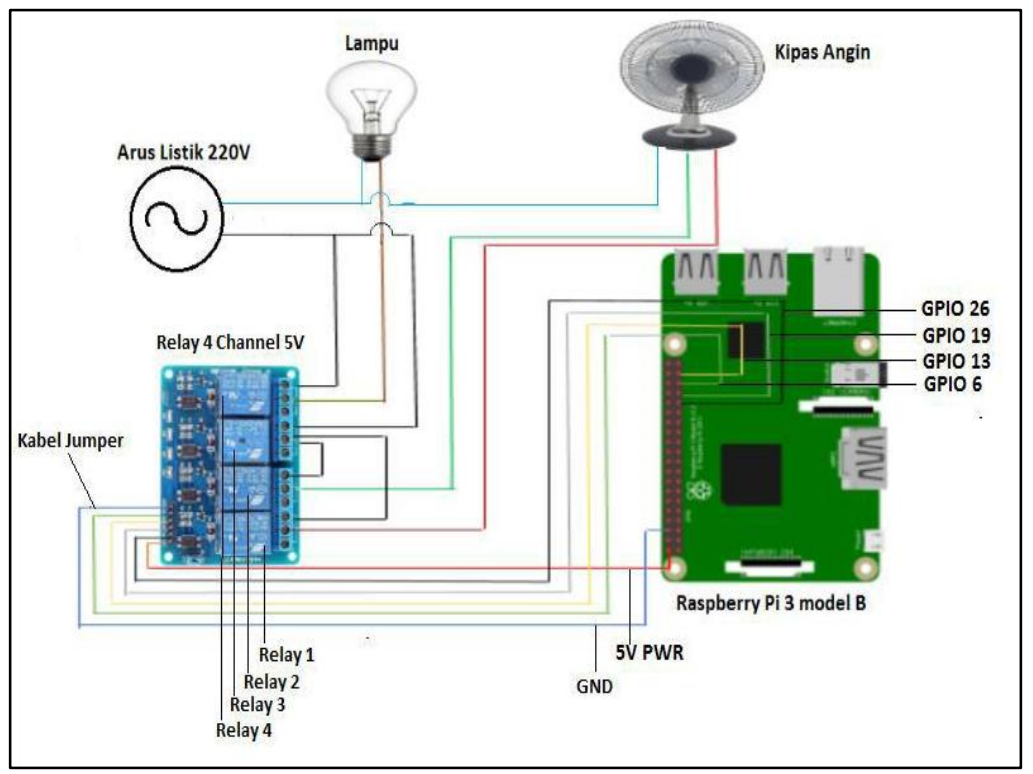

GAMBAR 1. Wiring diagram sistem kontrol smarthome

\section{Sistem Modulasi Digital}

Sistem modulasi digital yang digunakan dalam penelitian ini yakni menggunakan Wi-Fi yang bekerja pada frekuensi radio yang sangat tinggi yaitu pada frekuensi 2-6 GHz, dan untuk itu modulasi yang tepat adalah (Q-PSK), karena menggunakan empat titik pada diagram konstilasi, terletak di sekitar suatu lingkaran. Dengan empat tahap, QPSK dapat mendekode dua bit per simbol. Hal ini berarti dua kali dari BPSK. Analisa menunjukkan bahwa ini mungkin digunakan untuk menggandakan data rate jika dibandingkan dengan sistem BPSK. 


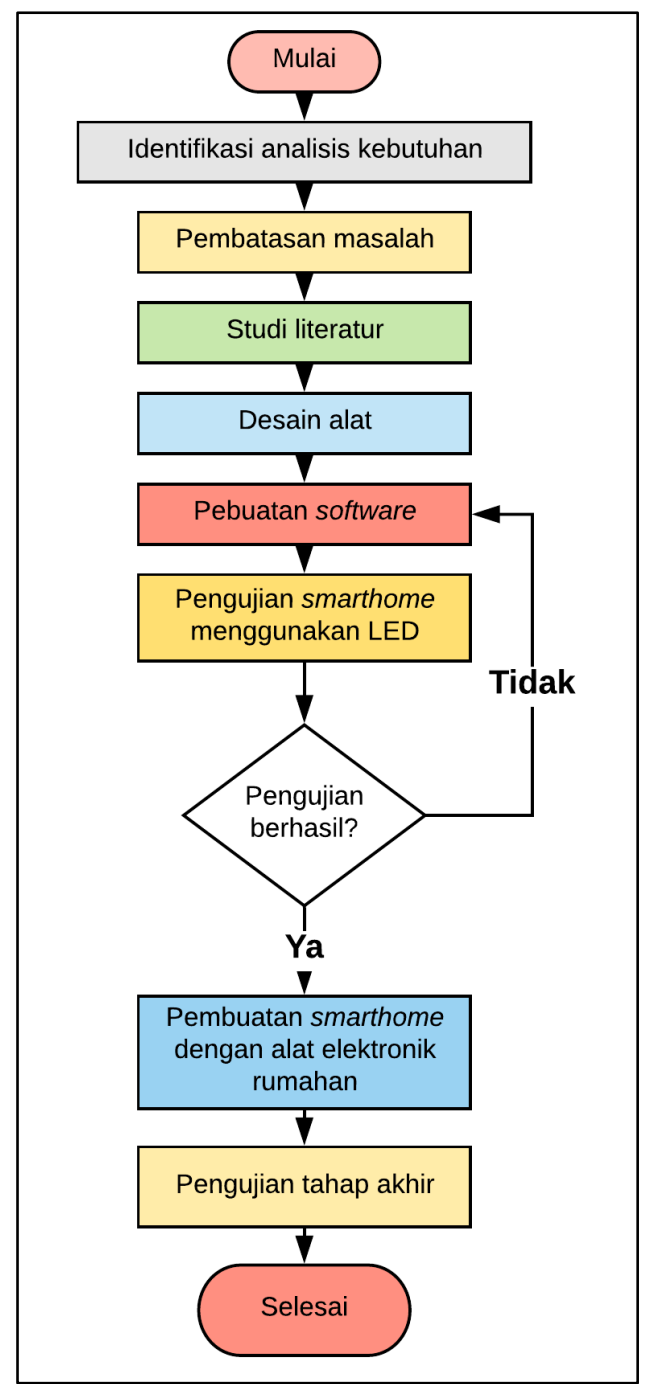

GAMBAR 2. Diagram alir penelitian

\section{Instalasi Operating System (OS)}

Sebelum melakukan pembuatan program untuk smarthome. Mikrokontroler ini butuh di install dengan OS (Operating System). Penulis menggunakan raspbian sebagai OS untuk Raspberry pi 3. Sistem operasi ini direkomendasikan melalui website resmi Raspberry Pi. Cara instalasinya tidak sama dengan cara instalasi sistem operasi pada umumnya seperti di PC atau laptop. Karena storage yang digunakan pada Raspberry adalah berupa SD card. SD card yang disarankan adalah SD card class 10 yang memiliki kecepatan menulis minimal $10 \mathrm{Mb} / \mathrm{s}$ dan minimal ukuran $8 \mathrm{~GB}$.

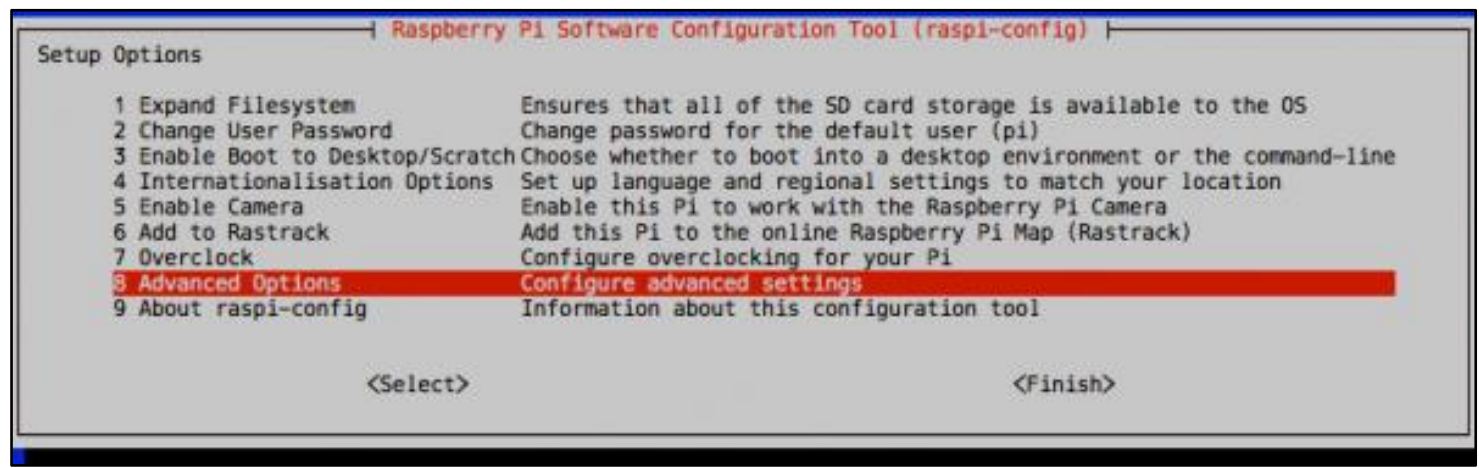

GAMBAR 3. Konfigurasi Raspberry Pi 3 


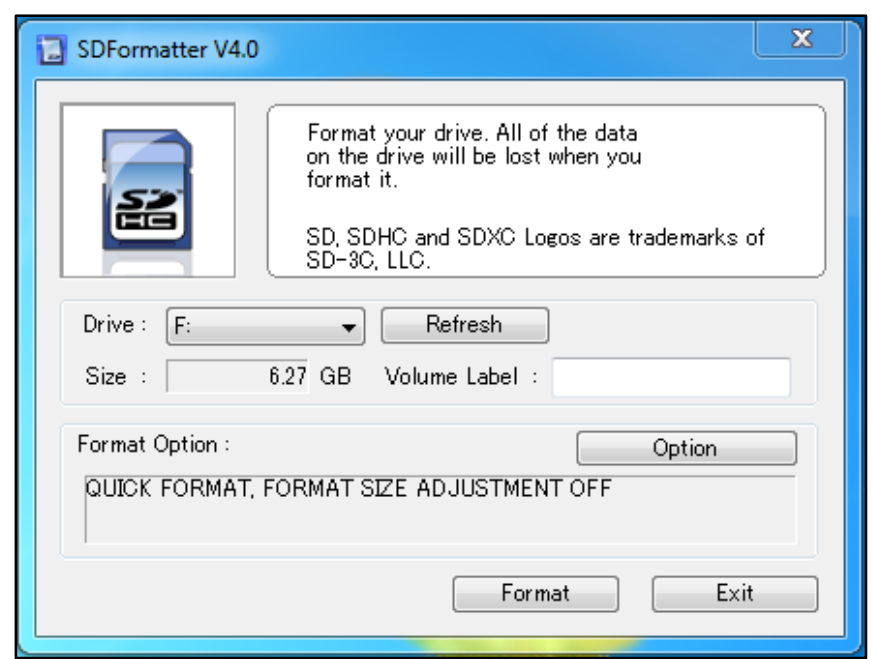

GAMBAR 4. SD Formatter

\section{HASIL DAN PEMBAHASAN}

\section{Hasil Rancang Smarthome}

Aplikasi rumah pintar (smart home) adalah aplikasi yang digunakan untuk mengendalikan peralatan elektronik rumah tangga yang berupa lampu, Kipas dan kamera. Pengendalian ini dapat dijalankan oleh pengguna melalui interface web yang akan terhubung dengan mikrokontroler, mikrokontroler yang digunakan dalam aplikasi ini adalah Raspberry Pi. Pada smarthome ini peralatan elektronik yang dikendalikan akan disimulasikan dengan menggunakan beberapa device elektronik.

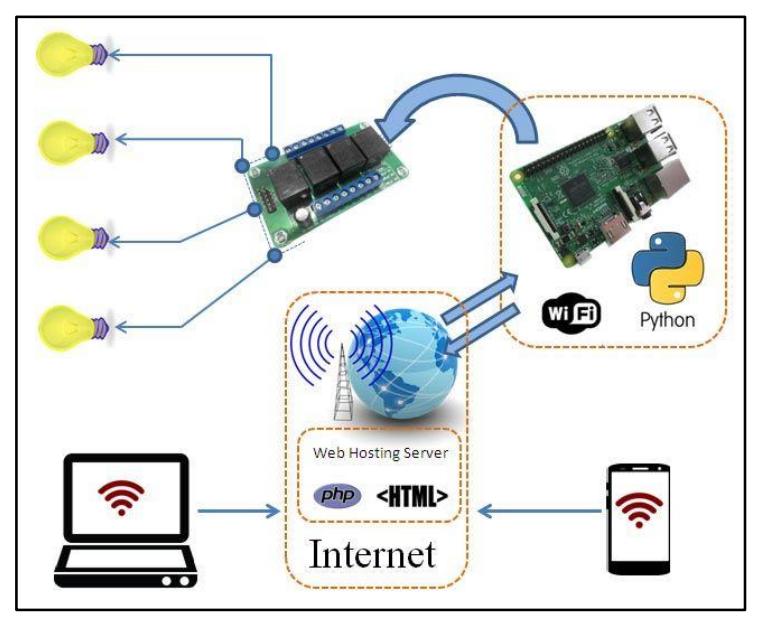

GAMBAR 5. Block diagram smarthome

\section{Hasil Uji Software pada Raspberry Pi 3}

Penggunaan uji software pada Raspberry Pi 3 di tujukan untuk mengontrol alat tersebut, dimana alat akan bekerja jika codingan benar. dalam Raspberry Pi banyak bahasa yang dapat digunakan. Di sini penulis menggunakan bahasa Python untuk memprogram alat tersebut. Langkah pertama sebelum proses mengkoding bahasa python nya, terlebih dahulu memastikan apakah OS (Operating System) yang digunakan raspi benar-benar sudah terinstal secara benar dan sempurna. 


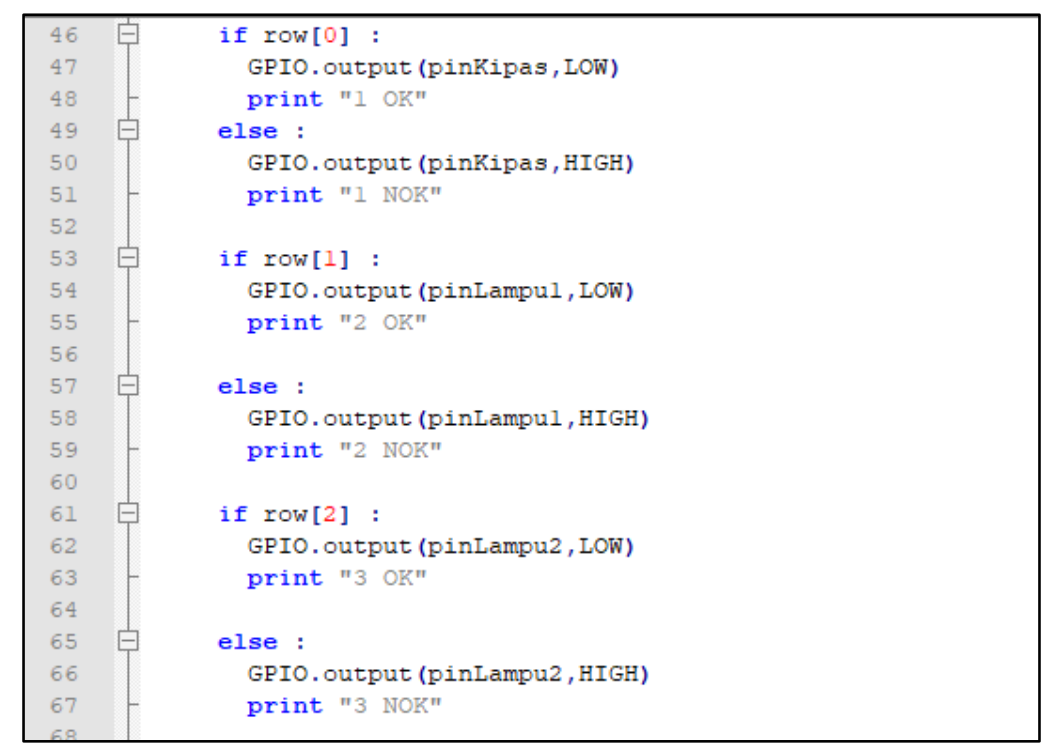

GAMBAR 6. Tampilan code pemrograman RasPi menggunakan Pyton

Tampilan ini membuktikan bahwa dengan codingan python dan dapat diinput langsung dari raspi, codingan ini dimaksudkan untuk menjalankan alat yang kita rancang, dengan memberikan logika sederhana pada alat tersebut. Setelah proses coding selesai dan telah tersimpan, selanjutnya kita membuka software putty, yaitu terminal virtual yang dapat mengakses raspberry pi. Caranya cukup mudah, hanya mengisi alamat Host atau IP address RasPi.

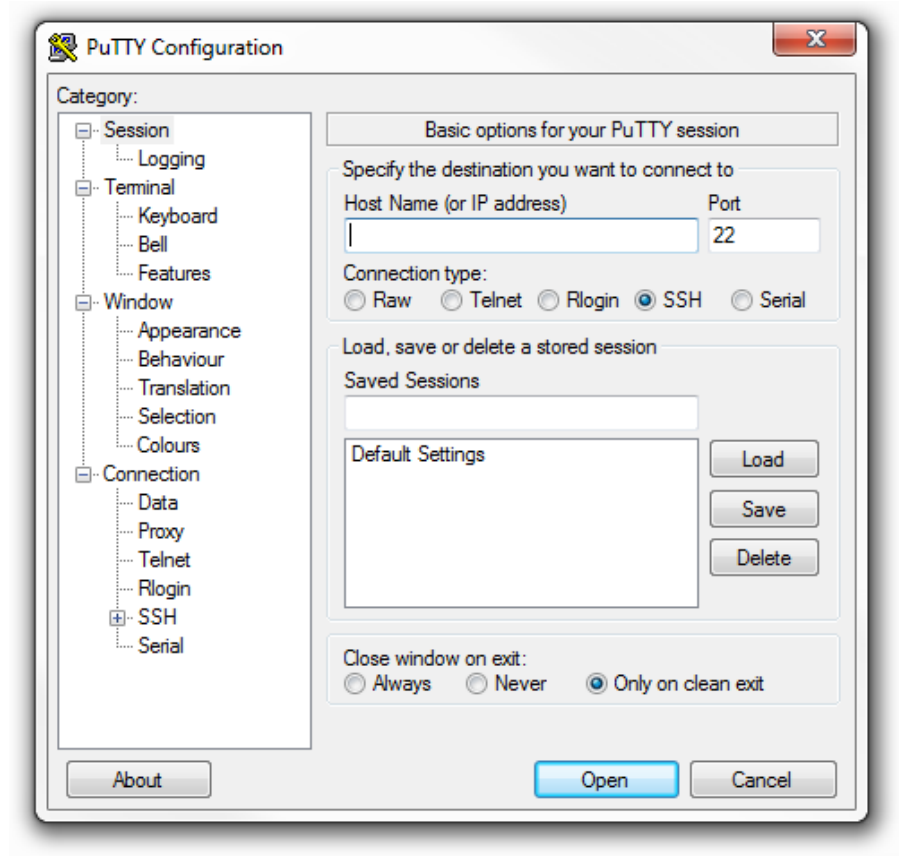

\section{GAMBAR 7. Aplikasi PuTTY}

\section{Hasil Uji Software Pada Website}

Setelah program dari Raspberry $\mathrm{Pi} 3$ selesai, maka tahap selajutnya yakni mengimplementasikan ke web, tadi kita sudah menembak database sebuah server, sekarang tinggal membuat sebuah program di database tersebut. Bahasa pemrograman yang dipakai pun sama seperti membuat website pada umumnya yaitu, ada Html 5 untuk tampilan interface nya, css, untuk mengatur layout dan font nya serta JavaScript untuk interaksi dan animasi sederhana, juga beberapa efek yang cukup kompleks dan berbagai widget yang dapat dikonfigurasikan. jQuery, pada intinya, adalah sebuah library yang berfungsi untuk memanipulasi DOM. DOM 
merupakan representasi struktural dari seluruh elemen pada sebuah laman web. Keberadaan jQuery menjadikan kerja pencarian, penyeleksian, dan manipulasi elemen-elemen DOM menjadi simpel dan mudah. Sebagai contoh, jQuery bisa dipergunakan untuk menemukan sebuah elemen dalam dokumen yang memiliki properti tertentu (misalnya: elemen dengan tag `h1'), kemudian mengubah satu atau beberapa atributnya (misalnya: warna, visibilitas), atau menjadikan elemen tersebut responsif terhadap suatu event (misalnya: klik mouse).

Selain penyeleksian dan manipulasi DOM dasar, jQuery menyajikan sebuah paradigma baru pada penanganan event oleh JavaScript. Penugasan event dan pendefinisian fungsi event callback dapat dilakukan dengan satu langkah dalam satu lokasi di dalam kode. jQuery juga dikembangkan untuk mendayagunakan berbagai fungsionalitas JavaScript yang paling sering dipakai (misalnya: fade in atau fade out ketika menentukan visibilitas elemen, juga bermacam animasi yang dimunculkan dengan memanipulasi properti-properti CSS).

\section{Design Layout Pada Web}

Karena penulis menggunakan web sebagai media control nya makanya penulis menggunakan sebuah server web untuk nantinya dikendalikan dari sana. Pembuatan program ini bertujuan untuk menghubungkan atau menjembatani antara software, Raspi dan Perangkat elektronik. Untuk itu diperlukan sebuah tampilan pada website tersebut untuk mempermudah mengatur device mana yang akan di kendalikan nantinya.

Untuk membuat sebuah tampilan web browser ada beberapa bahasa yang diperlukan seperti HTML, css dan JavaScript. Langkah pertama yang dibutuhkan adalah dengan membuat tampilan antarmuka dengan menggunakan HTML, dan mengatur nya dengan css (Cascading Style Sheet). Setelah itu kita bisa juga menambahkan efek menggunakan JavaScript

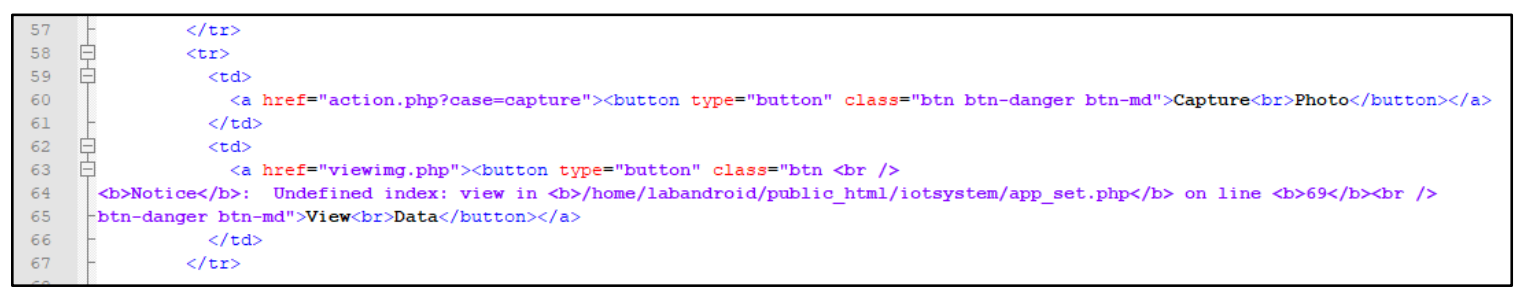

GAMBAR 8. Tampilan code pada web

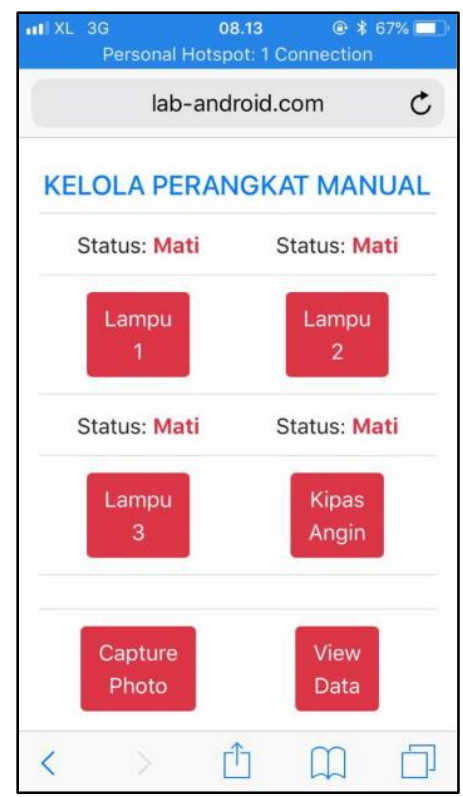

GAMBAR 9. Tampilan halaman web

Setelah melihat tampilan halaman, kemudian mencoba mengontrol smarthome pada website dengan mengklik $O N$ OFF pada setiap device elektronik rumah. Berikut tampilan pada 
gadget saat mencoba mengontrol on off elektronik rumah pada website, yang menunjukkan bahwa program untuk perangkat lunak smarthome berhasil dibuat dan antara RasPi dengan Web terkoneksi dengan baik.

\section{Flowchart Login dan Database}

Dengan adanya system login dengan menambahkan username dan password tentunya akan sangat bermanfaat dalam sisi keamanannya. User yang kita daftarkan dalam database juga bisa di tambah dan diatur, seperti super admin, user 1 dan seterusnya, dengan mengatur penggunaan masing-masing user tersebut tentu nya fungsi dari masing-masing user pun berbeda beda tergantung dari user yang diatur dalam sistem database nya.

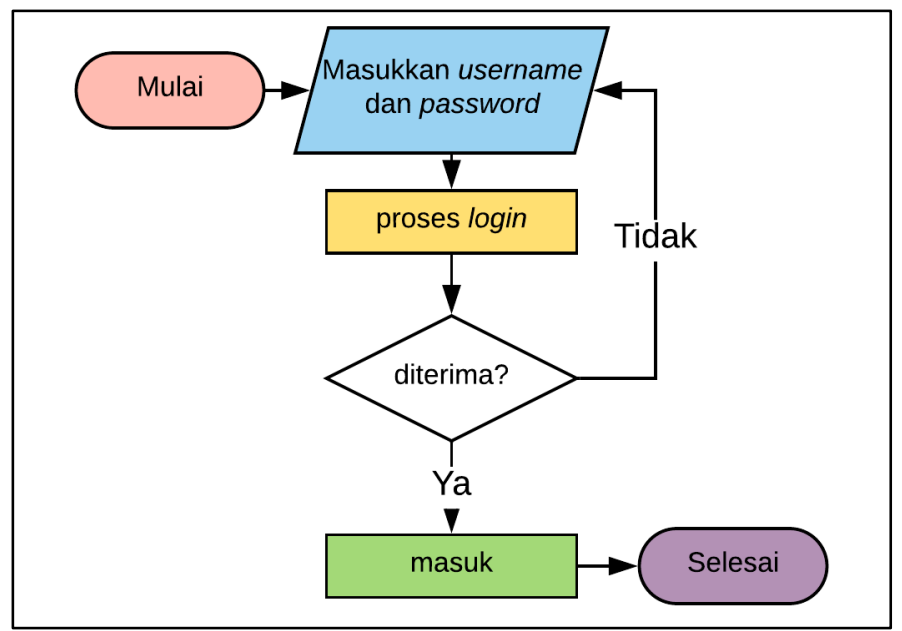

GAMBAR 10. Flowchart Login

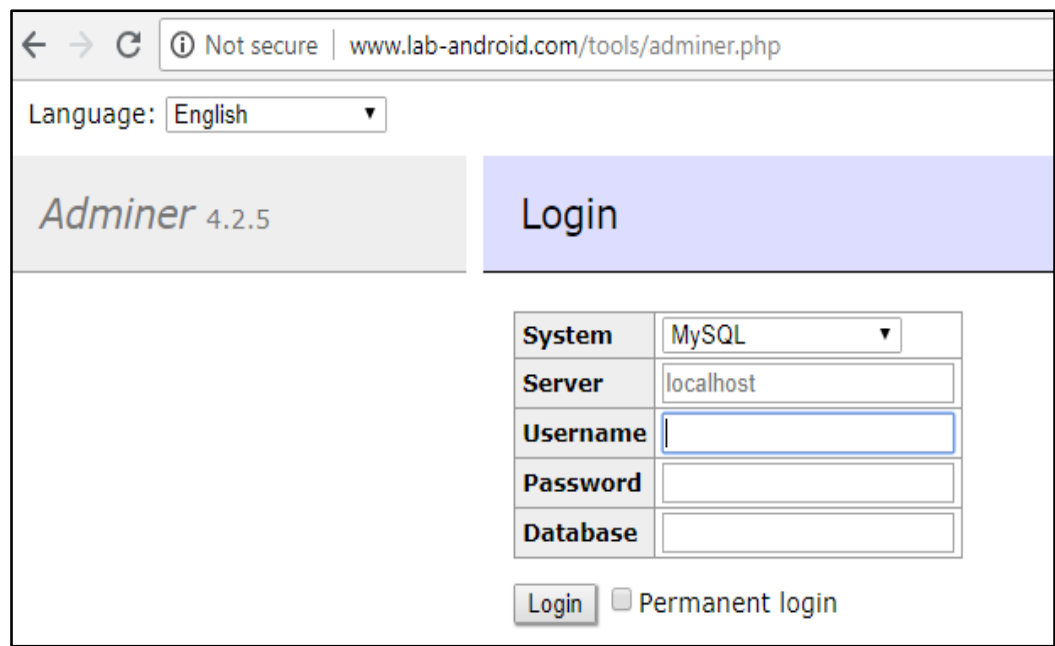

GAMBAR 11. Form login Database

Gambar 9 adalah tampilan dari login untuk mengakses sebuah database web yang nanti nya akan kita kontrol, seperti yang dibahas sebelum nya, ada beberapa hal yang harus di input seperti username, password dan database. Jika kita salah menginput maka database akan menolak dan tampilan akan otomatis kembali ke proses login. Database di sini juga berfungsi menyimpan dan merekam segala aktivitas yang terjadi pada web tersebut.

\section{Perakitan hardware}

Untuk merakit hardware tentunya membutuhkan alat dan bahan, maka langkah pertama adalah membuat raspi bisa terkoneksi baik dengan alat dan sumber listrik, di sinilah peran relay, relay berfungsi untuk memutus dan menyambung perangkat elektronik secara otomatis atau fungsi logika serta melindungi komponen lainnya dari kelebihan tegangan. Untuk itu perlu adanya 
ketelitian dalam proses penyambungan, karena yang kita pakai adalah arus listrik rumah sebesar $1300 \mathrm{~V}$, sementara raspi dan perangkat elektronik lainnya hanya membutuhkan daya yang kecil.

Kemudian langkah selanjutnya adalah memasang dan menyambungkan kabel-kabel raspi pada relay dan perangkat elektronik hasil output nya.

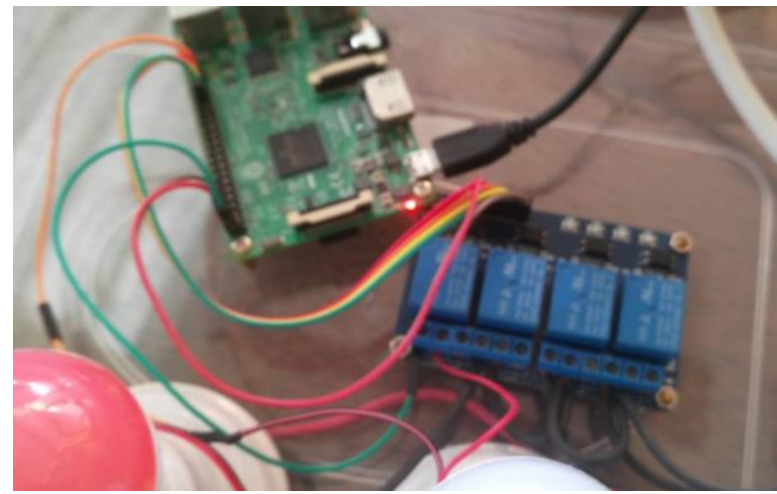

GAMBAR 3. Perakitan Raspberry Pi 3

Setelah semuanya kabel terinstal baru lah kita mengkoneksikan power raspi ke listrik, di sini kita menggunakan charger 3A untuk power supply nya. Untuk relay juga sama, menyambungkan ground ke power supply, begitu pula dengan device elektronik nya, di sini device yang digunakan akan masuk ke relay, hanya kamera yang masuk ke raspi dan relay, hal tersebut dikarenakan device tersebut memerlukan tambahan yaitu, untuk proses time capture dan database yang nantinya akan di proses dan di tampilkan lewat website.

\section{Hasil Uji Perangkat Keras}

Mempersiapkan komponen elektronika yang dibutuhkan seperti Rapsberry Pi 3, adaptor modul relay 4 channel, catu daya, lampu LED, sebuah kipas dan sebuah Webcam. Kemudian menyusun rangkaian menggunakan elektronik. Pertama- tama sambungkan Raspi yang sudah di upload program nya ke sumber listrik dengan charger. Lalu sambungkan pin GPIO power Raspi pada ground dan VCC pada relay, kemudian menyambungkan GPIO 26,19.13,6 (SPI1 MISO) atau input pada raspi. kemudin menyambungkan GROUND pada relay ke sumber listrik, dan satu nya lagi ke output pada device.

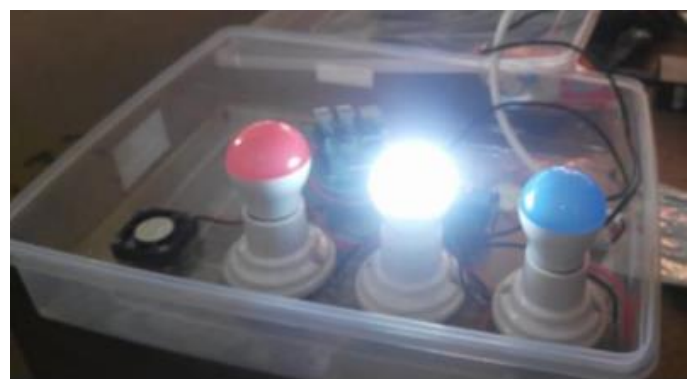

GAMBAR 43. Pengujian melalui Web

\section{Pengujian Perangkat Lunak}

Tabel 1. Tabel Pengujian satu device

\begin{tabular}{ccccccc}
\hline Pengujian & Lampu 1 & Lampu 2 & Lampu 3 & $\begin{array}{c}\text { Kipas } \\
\text { Angin }\end{array}$ & Kamera & Hasil \\
\hline 1 & 1 & 0 & 0 & 0 & 0 & OK \\
2 & 0 & 1 & 0 & 0 & 0 & OK \\
3 & 0 & 0 & 1 & 0 & 0 & OK \\
4 & 0 & 0 & 0 & 1 & 0 & OK \\
5 & 0 & 0 & 0 & 0 & 1 & OK \\
\hline
\end{tabular}


Tabel 1. menunjukkan bahwa ketika lampu 1 menyala, sisa perangkat yang lain tidak ikut menyala, begitu juga ketika pengujian kedua ketika lampu kedua dinyalakan sisa device lain juga tidak ikut menyala, lanjut dengan pengujian lampu ketiga, ketika dinyalakan sisa device nya tidak menyala juga dan tetap mati, sampai pengujian terakhir yaitu kipas angin, ketika dia menyala, device yang lain tidak ikut menyala dan tetap pada keadaan off.

Tabel 2. Pengujian dua device dinyalakan bersamaan

\begin{tabular}{ccccccc}
\hline Pengujian & Lampu 1 & Lampu 2 & Lampu 3 & $\begin{array}{c}\text { Kipas } \\
\text { Angin }\end{array}$ & Kamera & Hasil \\
\hline 1 & 1 & 1 & 0 & 0 & 0 & OK \\
2 & 0 & 1 & 1 & 0 & 0 & OK \\
3 & 0 & 0 & 1 & 1 & 0 & OK \\
4 & 0 & 0 & 0 & 1 & 1 & OK \\
\hline
\end{tabular}

Begitu juga dengan Tabel 2, saat dua device di nyalakan bersama, device yang tidak di nyalakan tidak akan ikut menyala atau tetap dalam keadaan mati. Sebagai contoh saat lampu 1 dan 2 dinyalakan, lampu ketiga, kipas dan kamera akan mati. Saat lampu 2 dan 3 yang dinyalakan lampu 1, kipas akan berada dalam keadaan mati, dan saat lampu 3 dan kipas yang dinyalakan, lampu 1, 2 dan kamera tetap mati. Begitu juga saat kipas dan kamera yang dinyalakan, lampu 1, 2 dan 3 akan mati.

Tabel 3. Pengujian 3 device dinyalakan bersamaan

\begin{tabular}{ccccccc}
\hline Pengujian & Lampu 1 & Lampu 2 & Lampu 3 & $\begin{array}{c}\text { Kipas } \\
\text { Angin }\end{array}$ & Kamera & Hasil \\
\hline 1 & 1 & 1 & 1 & 0 & 0 & OK \\
2 & 0 & 1 & 1 & 1 & 0 & OK \\
3 & 0 & 0 & 1 & 1 & 1 & OK \\
4 & 1 & 0 & 0 & 1 & 1 & OK \\
\hline
\end{tabular}

Tabel 3. kali ini menunjukkan saat tiga perangkat dinyalakan, sisa perangkat yang lain tidak ikut menyala. Ketika lampu 1,2 dan 3 dinyalakan bersama sama maka sisa perangkat yang lain seperti kipas dan kamera tidak ikut menyala. Begitu juga ketika hanya kipas dan kamera yang dinyalakan, maka lampu dan 1,2 dan 3 tidak akan ikut menyala juga.

Tabel 4. Pengujian 4 device dinyalakan secara bersamaan

\begin{tabular}{ccccccc}
\hline Pengujian & Lampu 1 & Lampu 2 & Lampu 3 & $\begin{array}{c}\text { Kipas } \\
\text { Angin }\end{array}$ & Kamera & Hasil \\
\hline 1 & 1 & 1 & 1 & 1 & 0 & OK \\
2 & 0 & 1 & 1 & 1 & 1 & OK \\
3 & 1 & 0 & 1 & 1 & 1 & OK \\
4 & 1 & 1 & 0 & 1 & 1 & OK \\
\hline
\end{tabular}

Tabel 4. pengujian dengan menyalakan ke 4 device atau perangkat sekaligus. Dan hasil nya ketika lampu 1,2, 3 dan kipas dinyalakan kamera tidak akan ikut menyala atau tetap dalam posisi mati, dan ketika lampu 2, lampu 3, kipas, dan kamera yang dinyalakan maka lampu 1 juga tidak akan ikut menyala, atau tetap dalam posisi mati. Dan terakhir saat lampu 1, lampu 2, kipas dan kamera, lampu 3 tidak akan ikut menyala atau tetap dalam posisi mati. Dari tabel-tabel uji tersebut dapat disimpulkan bahwa hasil yang di buat sesuai dengan perancangan dan system yang diinginkan oleh penulis, baik dari segi hardware maupun dari segi software. 


\section{KESIMPULAN}

Berdasarkan hasil yang diperoleh dari penelitian yang telah dilakukan, dapat disimpulkan beberapa hal yakni telah berhasil merancang bangun smarthome menggunakan Raspberry Pi 3 dan 4 channel relay 10A dan dapat berfungsi dengan baik. Selain itu, kami juga berhasil software untuk interface web dan terkoneksi dengan Raspberry Pi 3.

\section{REFERENSI}

[1] Choir, Affhol Arriska., 2012. Rancangan dan Uji Coba Otomatisasi Irigasi Kendi. Skripsi pada Institut Pertanian Bogor.

[2] Ignatius Prima Haryo Prabowo, Saptadi Nugroho, Darmawan Utomo, 2014, "Penggunaan Raspberry

[3] Pi Sebagai Web Server Pada Rumah Untuk Sistem Pengendali Lampu Jarak Jauh dan Pemantauan Suhu", Jurnal Ilmiah Elektroteknika, Vol. 13. No. 1. 111-124

[4] Nataliana. Decy, Syamsu. Iqbal, Giantara. Galih, 2014, "Sistem Monitoring Parkir Mobil menggunakan Sensor Infrared berbasis Raspberry Pi”, Jurnal Elkomika Institut Teknologi Nasional Bandung, Vol. 2. No. 1. 68-84.

[5] Bregman, David. Oktober 2010. "Smart Home Intelligence - The eHome that Learns ", (Online), Vol. 4. Diakses 05 Agustus 2018

[6] Darmawan, Hari, Faisal, Mohammad. 2015. "Rancang Bangun Home Automation Berbasis Web Menggunakan Raspberry Pi”, (Online).

[7] Huda, Syaiful, Dicky. Juli 2014. "Prototype Smart Classroom Berbasis Mikrokontroller Menggunakan Raspberry Pi dan Arduino”, (Online). Diakses 18 Maret 2018.

[8] Oktaviani, Wuri, Theresia. Maret 2014. "Perancangan User Interface Berbasis Web Untuk Home Automation Gateway Yang Berbasis IQRF TR53B”, (Online).

[9] Prasad, Sanjana. 2014. "Smart Surveillance Monitoring System Using Raspberry PI and PIR Sensor", (Online), Vol. 5(6). Diakses 05 Agustus 2018.

[10] Fuqin Xiong, 2006, "Digital Modulation Techniques", Artech House Telecommunication Library, The University of Michigan

[11] RAHAYU, MAYA. 28 Maret 2014. "Pengontrolan Alat Elektronika Melalui Media Wi-Fi Berbasis Raspberry Pi”, (Online), Vol 13. Diakses 02 Februari 2015.

[12] YURMAMA, FAJAR, TRI. 20 Juni 2009. "Perancangan Software Aplikasi Pervasive Smart Home", (Online), (http: //journal.uii.ac.id/index.php/Snati/arti cle/view/1239/1039. Diakses 28 Desember 2018).

[13] SOLICHIN, ACHMAD. 2009. "Pemograman Web dengan PHP dan MySql”, (Online). Diakses 22 April 2014. 